\title{
Assessing Consumer Behavior Components of Likeability Among Undergraduate Students Using Technology in the Classroom
}

\author{
James J. Tanoos ${ }^{1}$ \\ ${ }^{1}$ Purdue University, United States \\ Correspondence: James J. Tanoos, Purdue University, United States.
}

Received: January 13, 2020; Accepted: January 29, 2020; Published: January 29, 2021

\begin{abstract}
Analysis of market research in Western society began in the early twentieth century and eventually spawned interest in the prediction of consumer behavior preferences. More recently, inquiry into consumer behavior patterns has focused on digital technologies and online platforms. Through a series of likelihood ratio tests, this study will assess cognitive reactions of undergraduate students to a compilation of classic American television commercials. Various components for determining likeability will be used in order to steer future market research and digital branding strategies.
\end{abstract}

Keywords: likeability, consumer behavior, television commercial, branding, digital technology

\section{Introduction}

There are numerous studies related to consumer behavior preferences of audiences. These studies have often focused on younger demographics, because young consumers will bring in revenue over longer durations of time and thus are coveted more by multinational organizations. Today, these studies are less likely to be based on traditional television viewing consumption and instead focused on viewers of digital media. This study will analyze the consumer behavior preferences of undergraduate college students by analyzing students' cognitive reactions to classic television commercials.

\section{Literature Review}

In the US, television commercials (TVCs) first gained mainstream marketing focus in the 1950s, when the percentage of Americans with a television grew from $9 \%$ in 1950 to $90 \%$ by the end of the decade (Library of Congress, 2018). The use of TVCs in the US accelerated in the 1960s, modeling an emerging consumerism that relied on buying products more often (Zapf, 2016). The impact of American TVCs was greatest during the golden era of the American television networks in the early 1980s, when most Americans had only the three major networks on their television sets. During this era, mainstream advertisements were the norm because the viewing audience was not yet fragmented into niche cable channels, and most viewers couldn't yet record their favorite shows or fast-forward through commercials like today's audience, who can choose streaming services like Hulu and pay more for premium packages that don't include commercials. Today, variations of TVCs are presented in the form of 10 to 15 -second clips rather than the traditional 30 -second form, usually before a longer video clip is accessed.

Over the decades, American TVCs have reflected the values, marketing trends, cultural tendencies, and even comedic tastes of Americans (Rutherford, 1994; O’Barr, 2010). TVCs have even been attributed as having an impact on America's culture of materialism. TVCs have been a staple of an organization's marketing focus since the advent of television itself. Yunus (2016) detailed how brand image can be enhanced through TVCs due to commercials' ability to help viewers "to see the opportunities" on their screens in a way that other media doesn't necessarily provide.

The popularity of TVCs has spawned numerous academic studies on their effects. These studies have focused on consumer behavior topics such as product wear out effects (Calder \& Sternthal, 1980), variables prompting consumer acceptance (Belch, 1982), repetition and commercial length (Rethans et al., 1986), and consumer recall effects (Singh et al., 1988).

In particular, TVCs have been analyzed from the perspective of various consumer age cohorts to investigate their impact. Younger consumers are coveted more in multinational organizations' advertising because younger consumers who are loyal will make more money for those organizations over time. For instance, organizations pay 
more for TVCs during programs with a younger demographic of viewers. Over the years, the impact of TVCs on the preferences of children (Blanc, 1953; Resik et al., 1977; Jeffrey et al., 1980; Galst, 1980; Greer et al., 1982) and teenagers (Wainwright, 1980, Lee \& Browne, 1995; Ross \& Stein, 2008; Shea, 2008) has been commonly studied. Of particular relevance to this study is the research on the effects of TVCs on college students. In the past, the consumer behavior tendencies of college students have been studied to assess the impact of TVCs on topics such as economics (Paden, 1977), tobacco advertising (Crawford, 2014), and sexism (Kassin et al., 2010).

Pedagogies related to the utilization of technology in the classroom has been broadly studied (Tiene \& Luft, 2001; Tiene \& Luft, 2002; Bitter \& Pierson, 2005; Schifter, 2008; Boles, 2011; Hicks, 2011; Rehmat \& Bailey, 2014; Magana, 2017). In addition, the effect of technology in marketing and consumer behavior (Sweeney, 1972, Rust, 2006; Milne \& Bahl, 2010; Belch \& Belch, 2011; Moutinho et al., 2014: Simonson \& Rosen, 2014; Spotts, 2014; Woersdorfer, 2017; Fasasi, 2019) have been studied for generations.

YouTube and other streaming services have adopted Facebook's model of allowing users to click a "thumbs up" or "like" to show approval for a video clip. Twitter allows users to click a heart to display viewer approval. An abundance of "likes" for an artist can result in a deal from a record label, while constantly gaining a high number of Twitter hearts can result in an actor being cast in a film. Truly, popularity is attributed to the quantity of likes, and organizations and marketers pay attention.

A "like" is and has been said to be a measure of self-esteem and self-work for young people today, and has become sought-after (Puccio \& Havey, 2016; Freitas, 2017; Wolk, 2017; Desjarlais, 2019), and has evolved into an allencompassing term to describe approval (Havery \& Puccio, 2016; Singer \& Brooking, 2018). Further, organizations today spend time and resources in marketing via social media in hopes of obtaining likes (Anderson, 2010; Evans, 2012; Charlesworth, 2014; Kellett, 2017; Samuel, 2017; Bartnik, 2018; Dahl, 2018).

Organizations today spend huge amounts of money on marketing research to build their brands, and technology will play an increased role in marketing research (Verklin \& Kanner, 2007; Yunus, 2016). TVCs will continue to be part of an organization's marketing budget and will continue to evolve from television-specific to being integrated into technology-based online and social media marketing efforts (Newth, 2013; Speck, 2013; Watkins, 2018).

\section{Methodology}

Previous research on TVCs has used predictive studies, a type of experimental design used to ascertain when and in what situations an event will occur. In this model, the goal is to discover which types of commercials or attributes within commercials prompt viewers to react cognitively, leading to a specific consumer behavior response. Past studies attempted to form relational or causal hypotheses.

This study analyzed the cognitive consumer behavior of undergraduate college students toward "classic" American TVCs spanning multiple eras. Specifically, a list of the 50 most influential commercials was developed based on various surveys of marketing industry specialists (Elliott, 1995; EW, 1997; Advertising Age, 1999; Kanner, 1999; Vancheri, 1999; Harry \& Stall, 2002; Kanner, 2003; Smith, 2003; Plunkett, 2006; Riggs, 2006). In efforts to gauge students' response to these commercials in the same fashion that they react to videos on social media, their cognitive reactions were gathered. An immediate reaction was preferred rather than after time to reflect and conduct further investigation because the like of a student is much like an instant reaction on a social media post, such as when someone immediately decides whether to click the "thumbs-up" or other synonymous symbol of a "like". As such, commercials were intended to analyze the likability, whereas young people today rate how much they "like" these classic, influential commercials of the past.

The same commercials were shown to students in three institutions of higher education (two public, one private) from 2006-2019. The students surveyed were majoring in either a business- or technology-related field. Each TVC was played in class in its entirety, along with a brief script introducing it. Students were then asked to rate each commercial on five components: 1) Marketability, 2) Memorability, 3) Likeability, 4) Chance of Success, and 5) Level of Classic-ness. Each item was ranked on a scale of $1=$ very low, $2=$ low, $3=$ medium, $4=$ high, $5=$ very high. In addition, the 50 commercials were labeled as having a script intended to be humorous or comedic.

As such, the model contained the following discrete variables, which served as predictors, in the experimental design: 1) Gender, 2) Major, and 3) If the commercial was intended to be comedic (Humor). Since the various years in which the commercials were produced (Year) had so many values, the year was treated as a continuous variable in order to provide for the best explanation within the model. To best interpret the intercept within the model, the year was centralized and thus could take on any value (calculated as year = year - mean (years)). This process scaled its value, whereas the centered year $=0$, or the mean value of all years. 
To allow the algorithm to develop the relationships between variables to best predict future values (i.e., fit the model), a generalized linear mixed model was determined to be the best fit. This model is a type of predictor containing random and fixed variables in order to form hypotheses. In this instance, the commercials themselves served as random factors and were interpreted as to how they affected the relationships and interactions between Gender, Major and the Commercial, whereas the interactions among Gender, Major, Humor, and Year were designated as fixed factors. By conducting this multiple hypothesis test (a style of Chi-square test or a more specific style of generalized linear model) to explain the variance (which is designed to test for homogeneity), the final model for each interaction of the five components was determined (see appendix). The final model for "likeability" is seen in Figure 1 below.

$$
\begin{gathered}
\text { Likeability }_{i j m k}=\text { Humor }_{j}+\left(\text { Gender }^{*} \text { Major }_{i m}+\text { Commercial }_{k}\right. \\
+\left(\text { Commercial }_{\text {Gender }}\right)_{i k}+\left(\text { Commercial } * \text { Major }_{m k}+\text { error }_{i j m k}\right. \\
i=j=m=1,2 ; k=1,2,3 \ldots, 50 ; \text { Commercial }_{k} \sim \mathrm{N}(0,0.193) ; \text { error }_{i j m k} \sim \mathrm{N}(0,0.982) \\
(\text { Commercial } * \text { Major })_{m k} \sim \mathrm{N}(0,0.059) ;(\text { Commercial } * \text { Gender })_{i k} \sim \mathrm{N}(0,0.026) ;
\end{gathered}
$$

Figure 1. Model for Likeability

\section{Results \& Future Studies}

Likelihood ratio tests were conducted to examine and analyze the different statistical models, using the variables in the above model to interpret how they interact with each other. Alpha $=.05$ was utilized; those variables testing at a $p$-value $>.05$ were not significant, and those at $p$-value $<.05$ were significant.

From the likeability model and likelihood ratio tests, it can be confirmed that the "Year" in which the commercial was produced does not have a significant effect on Likeability, with a $p$-value > .05 . However, the same tests show that "Humor" and the interaction of "Gender" and "Major" have significant effects on the likeability mean, with $p$-values $<.05$. These variables are deemed significant and thus do play an important role in Likeability (see the model summary's code output report of the commercial dataset below). Males majoring in a technology-related field tended to like the commercials more so.

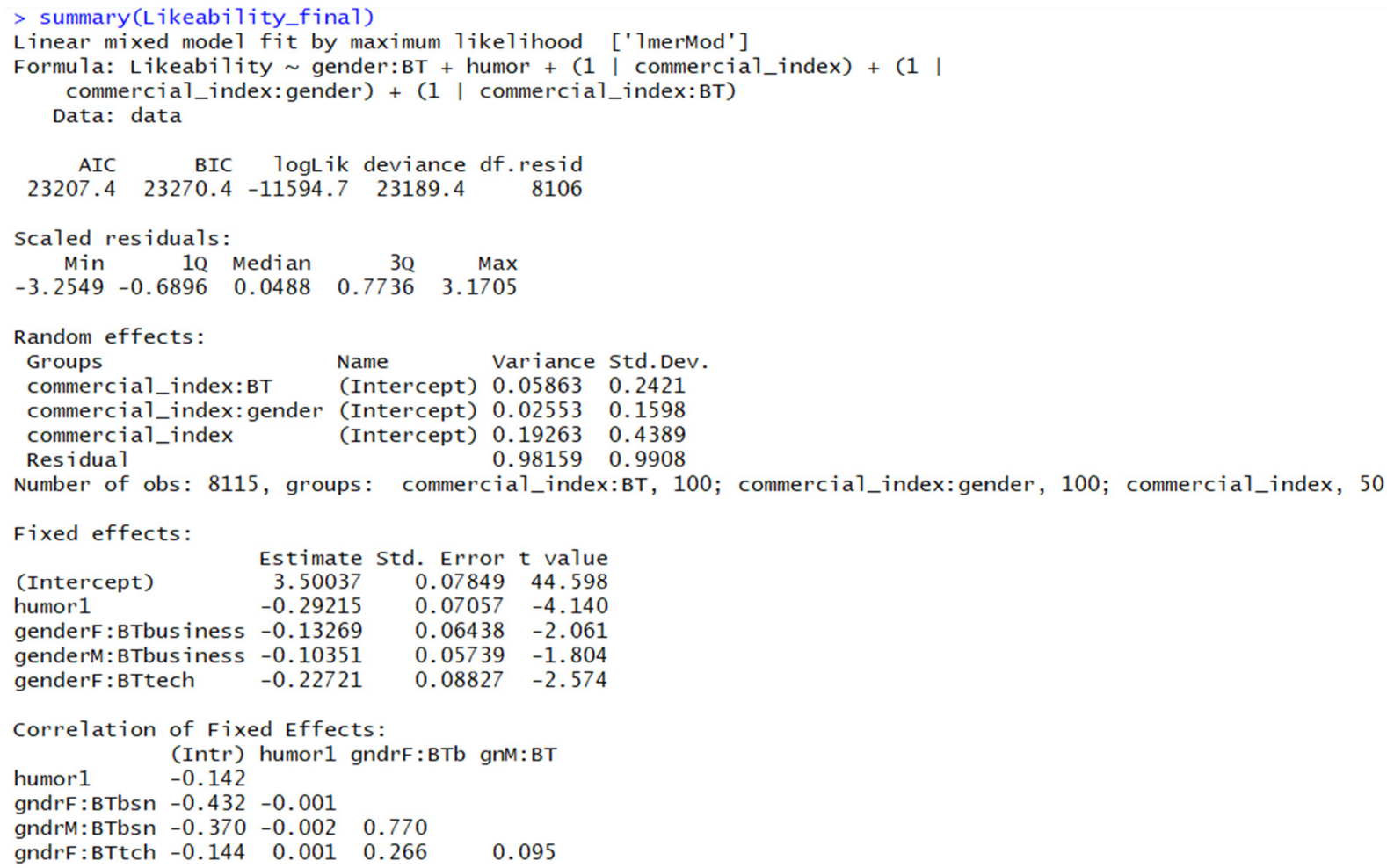

Figure 2. Likeability Model's Code Output Report 
Figure 3 is a visual depiction of the relatively higher scores of likeability attributed by males. Since the average scores of males majoring in technology rated the commercials at a statistically significant rate for likeability, it may be inferred that they tend to feel that commercials make the products and the organizations more likeable. Future researchers may wish to assess which of these commercials were written, produced, and cast by males employed in technology-related fields, and whether more modern commercials with female actors and scriptwriters were found to be more likeable by females.

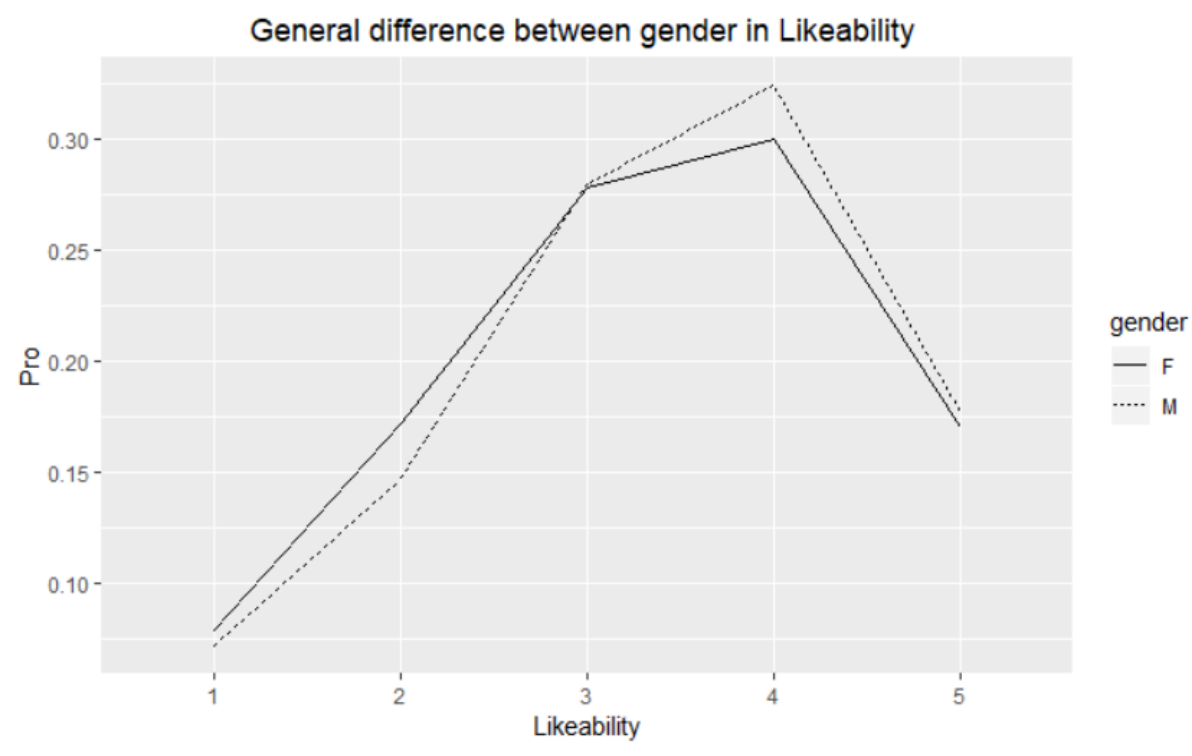

Figure 3. Likeability Scores: Difference in Gender

Figure 4 shows the difference in likeability scores by major. Students majoring in technology-related fields generally rate likeability of the commercials at higher rates, but not significantly, unless they were also male students. Subsequently, it may be pondered for future studies whether male students with proclivities to technology in general are more likely to feel that digital forms of classic commercials are more likeable since they are more relatable in the form in which they were viewed in class.

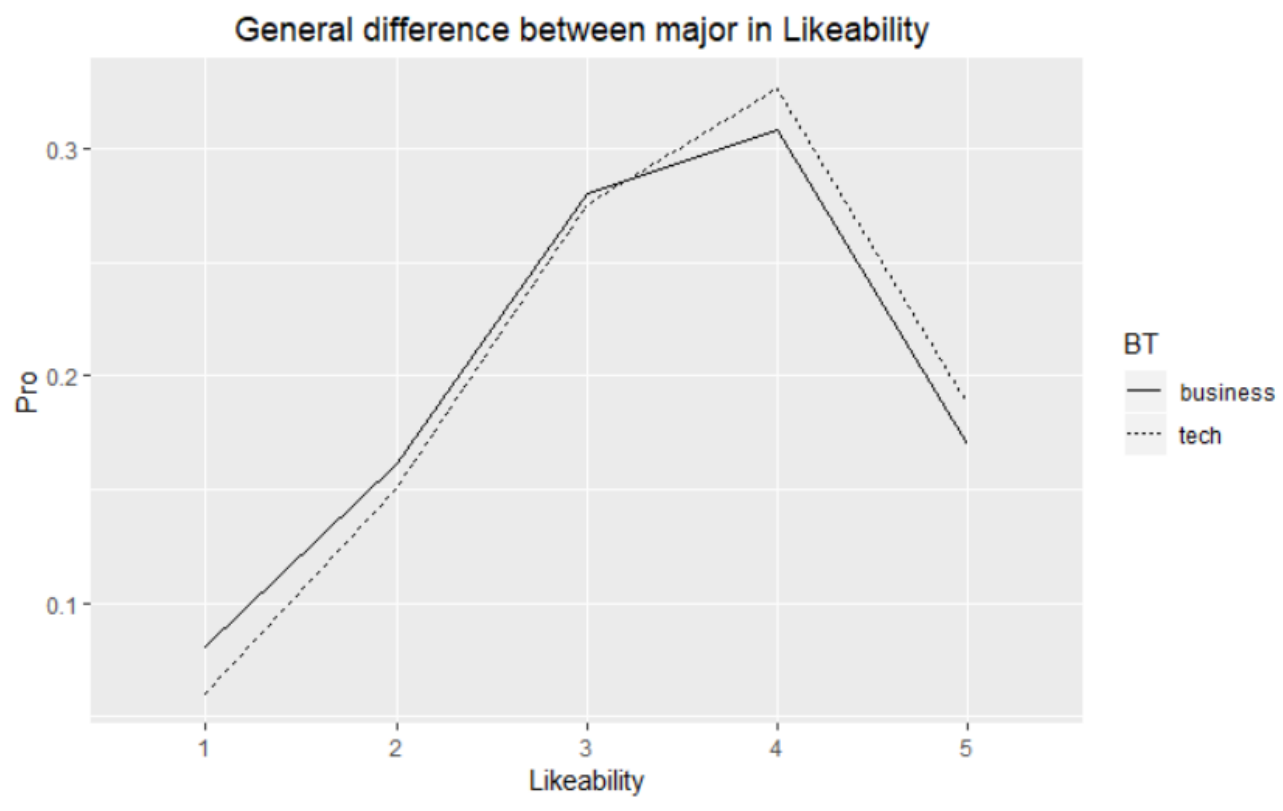

Figure 4. Likeability Scores: Difference in Major 
In addition, more humorous commercials generally rated higher in likability, with a $p$-value $<.05$, which means that it is not likely to be due to chance that commercials intended to be funny were more likely to be perceived as more likeable. However, it should be noted that several commercials that were unintentionally funny ("campy") were not considered in the sample set of commercials labeled "Humor". In addition, since the year in which the commercial was produced does not have a significant effect and/or interaction on likeability, it may also be ascertained that just because a TVC is older or less modern does not indicate that younger viewers are not receptive to it and/or are likely to reject it just based on age. This may provide those in an organization more incentives to re-release older versions of their organizations' TVCs for younger demographics of viewers who may not be aware of the classic versions of the organization's past seminal advertisements. Organizations with classic commercials from the past may wish to take the opportunity to re-release them in digital form for new generations of viewers to gain likes.

Since it is not due to chance that the males found the commercials more likeable, future studies should analyze whether allowing for time and reflection through assignments and research about the commercials prompts males to feel the brand and/or products in the commercial are less marketable than the cognitive reaction from class. Furthermore, streaming services that employ models of allowing users to click a "thumbs up" or "like" to show approval for digital videos.

Segmentation based on gender should be at the forefront of market research. Future researchers may also assess whether technology-related majors rated the commercials higher in likeability compared to all other majors (not just business-related majors). While much attention in the field of marketing segmentation has been based on the age of the consumer, more attention should be spent on consumer behavior assessment based on gender.

\section{References}

Advertising Age. (1999). Ad Age Advertising Century: Top 100 campaigns. Retrieved from https://adage.com/article/special-report-the-advertising-century/ad-age-advertising-century-top-100advertising-campaigns/ 140150 .

Anderson, E. (2010, July 24). Social Media Marketing: Game theory and the emergence of collaboration. Berlin, Germany: Springer Science \& Business Media.

Bartnik, M. (2018, May 8). The 8 Pillars of Social Media Marketing In 2018: Learn how to transform your online marketing strategy. Scotts Valley, CA: CreateSpace Independent Publishing Platform.

Belch, G., \& Belch, M. (2012). Advertising and promotion: An integrated marketing communications perspective. New York, NY: McGraw-Hill Irwin.

Bitter, G., \& Pierson, M. (2005). Using Technology in the Classroom, Volume 1. Boston, MA: Allyn \& Bacon Publishing.

Blanc, S. (1953). Science Instruction over Commercial Television. The Science Teacher, 20(6), 287-290.

Boles, S. (2011). Using Technology in the Classroom. Science Scope, 34(9), 39-40.

Calder, B. \& Sternthal, B. (1980). Television Commercial Wear Out: An Informative Processing View. Journal of Marketing Research, 17(2), 173-186. https://doi.org/10.2307/3150928

Charlesworth, A. (2014, November 20). An Introduction to Social Media Marketing. New York, NY: Routledge. https://doi.org/10.4324/9780203727836

Crawford, E. (2014). Tobacco Goes to College: Cigarette advertising in student media. Jefferson, NC: McFarland \& Company.

Dahl, S. (2018, March 5). Social Media Marketing: Theories and applications. Bridgeport, IL: SAGE Publishing.

Desjarlais, M. (2019). The Psychology and Dynamics Behind Social Media Interactions. Hershey, PA: IGI Global. https://doi.org/10.4018/978-1-5225-9412-3

Elliott, S. (1995). The Media Business \& Advertising: A new ranking of the 50 best television commercials ever made. New York Times. Business Section.

Entertainment Weekly. (1997). The 50 Best Commercials of All-Time. Staff Writer. Retrieved from https://ew.com/article/1997/03/28/50-best-commercials-all-time/.

Evans, D. (2012, February 15). Social Media Marketing: A hour a day. Indianapolis, IN: John Wiley \& Sons Inc.

Fasasi, L. (2019). Digital Marketing: Which effect does it have on the financial performance of firms? Munich, Germany: Grin Verlag Publishing. 
Freitas. D. (2017). The Happiness Effect: How social media is driving a generation to appear perfect at any cost. Cary, NC: Oxford University Press.

Galst, J. (1980). Television Food Commercials and Pro-Nutritional Public Service Announcements as Determinants of Young Children's Snack Choices. Child Development, 51(3), 935-938. https://doi.org/10.2307/1129492

Greer, D., Potts, R., Wright, J., \& Huston, A. (1982). The Effects of Television Commercial Form and Commercial Placement on Children's Social Behavior and Attention. Child Development, 53(3), 611-619. https://doi.org/10.2307/1129372

Harry, S., \& Stall, S. (2002). As Seen on TV: 50 Amazing Products and the commercials that made them famous. Philadelphia, PA: Quirk Books.

Havery, A., \& Puccio, D. (2016). Sex, Likes and Social Media: Talking to our teens in the digital age. London, England: Ebury Publishing.

Hicks, S. (2011). Technology in Today's Classroom: Are you a tech-savvy teacher? The Clearing House, 84(5), 188-191. https://doi.org/10.1080/00098655.2011.557406

Jeffrey, D., McLellarn, R., Hickey, S., Lemnitzer, N., Hess, J., \& Stroud, J. (1980). Television Food Commercials and Children's Eating Behavior: Some empirical evidence. Journal of the University Film Association, 32(12), 41-43.

Kanner, B. (1999). 100 Best TV Commercials: And why they worked. New York, NY: Crown Publishing.

Kanner, B. (2003). The Super Bowl of Advertising. How the commercials won the game. New York, NY: Publishers Weekly.

Kassin, S., Fein, S., \& Markus, H. (2010). Social Psychology. Boston, MA: Cengage Learning.

Kellett, J. (2017. March 8). Social Media Marketing: Get 10000 targeted facebook likes in 10 days. Scotts Valley, CA: CreateSpace Independent Publishing Platform.

Lee, E., \& Browne, L. (1995). Effects of Television Advertising on African American teenagers. Journal of Black Studies, 25(5), 523-536. https://doi.org/10.1177/002193479502500501

Magana, S. (2017). Disruptive Classroom Technologies: A framework for innovation in education. Thousand Oaks, CA: Corwin Publishing.

Milne, G., \& Bahl, S. (2010). Are There Differences Between Consumers' and Marketers' Privacy Expectations? A segment- and technology-level analysis. Journal of Public Policy \& Marketing, 29(1), 138-149. https://doi.org/10.1509/jppm.29.1.138

Moutinho, L., Bigne, E., \& Manrai, A. (2014). The Routledge Companion to the Future of Marketing. Batavia, IL: Taylor \& Francis Group. https://doi.org/10.4324/9780203103036

Newth, T. (2013, October 30). The Ad-Makers: How the best tv commercials are produced. Boca Raton, FL: CRC Press.

Paden, D. (1977). The use of Television in Teaching Basic Economics at the College Level. The Journal of Economic Education, 9(1), 21-27. https://doi.org/10.2307/1182210

Plunkett, J. (2006). Plunkett's Advertising \& Branding Industry Almanac. Houston, TX: Plunkett Research Ltd.

Rehmat, A. \& Bailey, J. (2014). Technology Integration in a Science Classroom: Preservice teachers' perceptions. Journal of Education Technology \& Society, 19(4), 203-212. https://doi.org/10.1007/s10956-014-9507-7

Resik, A., \& Stern, B. (1977). Children's Television Advertising and Brand Choice: A laboratory experiment. Journal of Advertising, 6(3), 11-17. https://doi.org/10.1080/00913367.1977.10672702

Rethans, A., Swasy, J., \& Marks, L. (1986). Effects of Television Commercial Repetition, Receiver Knowledge, and Commercial Length: A test of the two-factor model. Journal of Marketing Research, 23(1), 50-61. https://doi.org/10.1177/002224378602300106

Riggs, T. (2006). Encyclopedia of Major Marketing Campaigns. Farmington Hills, MI: Gale Group.

Ross, S., \& Stein, L. (2008). Teen Television: Essays on programming and fandom. Jefferson, NC: McFarland \& Company.

Rust, R. (2006, July). From the Editor: The maturation of marketing as an academic discipline. Journal of Marketing, 70(3), 1-2. https://doi.org/10.1509/jmkg.70.3.1 
Rutherford, P. (1994, January 1). The New Icons? The art of television Advertising. North York, Canada: University of Toronto Press. https://doi.org/10.3138/9781442681866

Samuel, K. (2017). Facebook Marketing: Guide to get 10000 likes and followers in 15 days for facebook page. Scotts Valley, CA: CreateSpace Independent Publishing Platform.

Schifter, C. (2008). Infusing Technology into the Classroom: Continuous practice improvement. Hershey, PA: IGI Global publishing. https://doi.org/10.4018/978-1-59904-765-2

Shea, K. (2008). Teens in the U.S.A. North Mankato, MN: Compass Point Books.

Simonson, I. \& Rosen, E. (2014). Absolute Value: What really influences customers in the age of (nearly) perfect. London, UK: HarperBusiness publishing.

Singer, P. \& Brooking, E. (2018). LikeWar: The Weaponization of Social Media. New York, NY: Eamon Dolan/Houghton Mifflin Harcourt.

Singh, S., Rothschild, M., \& Churchill, G. (1988). Recognition Versus Recall as Measures of Television Commercial Forgetting. Journal of Marketing Research, 25(1), 72-80. https://doi.org/10.2307/3172926

Smith, S. (2003). America's Greatest Brands. State College, PA: The American Brands Council. https://doi.org/10.1086/380539

Speck, B. (2013, October 31). The Multimodal Analysis of Television Commercials. Valencia, Spain: University of Valencia.

Spotts, H. (2014). Marketing, Technology, and Customer Commitment in the New Economy. New York, NY: Springer Publishing.

Sweeney, D. (1972, October). Marketing: Management technology or social process? Journal of Marketing, 36(4), 3-10. https://doi.org/10.1177/002224297203600402

Tiene, D., \& Luft, P. (2001). Teaching in a Technology-Rich Classroom. Education Technology, 41(4), 23-31.

Tiene, D., \& Luft, P. (2002). Examining the Long-Term Impact of a One-Semester Technology-Rich Classroom Experience. Education Technology, 42(5), 41-47.

Vancheri, B. (1999). Perfect Pitches: TV Guide salutes 50 best commercials. Pittsburgh Post-Gazette. TV and Radio Section.

Verklin, D., \& Kanner, B. (2007). Watch This, Listen Up, Click Here: Inside the 300-billion-dollar business behind the media you constantly consume. Indianapolis, IN: John Wiley \& Sons Inc.

Wainwright, C. (1970). Television Commercials: How to create successful TV advertising. New York, NY: Hastings House.

Watkins, E. (2018.). Guide to Advertising Technology. Retrieved from https://www.cjr.org/tow_center_reports/theguide-to-advertising-technology.php.

Woersdorfer, J. (2017). The Evolution of Household Technology and Consumer Behavior, 1800-2000. Philadelphia, PA: Routledge publishing. https://doi.org/10.4324/9781315203799

Wolk, L. (2017, August 29). Girls Just Want to Have Likes: How to raise confident girls in the face of social media madness. New York, NY: Morgan James Publishing.

Yunus, U. (2016). Enhance the brand image through Television Commercial (TVC): A case study "Create your chance". Humaniora, 7(4), 569-576. https://doi.org/10.21512/humaniora.v7i4.3609

Zapf, H. (2016). Handbook of Ecocriticism and Cultural Ecology (Vol. 2). Berlin, Germany: de Gruyter Mouton. https://doi.org/10.1515/9783110314595 


\section{Appendix A.}

Top 50 List of Classic American Television Commercials and Survey Data

\begin{tabular}{|c|c|c|c|c|c|c|c|}
\hline Commercial Name & Year & $\begin{array}{l}\text { Humor } \\
(Y / N)\end{array}$ & Bus & Tech & $M$ & $\boldsymbol{F}$ & $N$ \\
\hline Pepsi Michael Jackson & 1983 & $\mathrm{~N}$ & 162 & 46 & 104 & 105 & 209 \\
\hline Bartles \& Jaymes "Thank You for Your Support" & 1985 & $\mathrm{Y}$ & 150 & 59 & 104 & 105 & 209 \\
\hline Mr. Clean original & 1958 & $\mathrm{~N}$ & 148 & 47 & 101 & 94 & 195 \\
\hline Head On & 2006 & $\mathrm{~N}$ & 150 & 48 & 100 & 98 & 198 \\
\hline Grey Poupon & 1987 & $\mathrm{Y}$ & 153 & 45 & 100 & 98 & 198 \\
\hline Gap Khaki's Swing & 1998 & $\mathrm{~N}$ & 149 & 55 & 97 & 97 & 194 \\
\hline Wendy's "Where's the Beef" & 1984 & $\mathrm{Y}$ & 135 & 46 & 90 & 91 & 181 \\
\hline More Doctor's Smoke Camels & 1949 & $\mathrm{~N}$ & 167 & 49 & 105 & 111 & 216 \\
\hline Mars Blackmon Air-Jordan & 1988 & $\mathrm{Y}$ & 132 & 53 & 93 & 92 & 185 \\
\hline 1974 Ford Mustang & 1974 & $\mathrm{~N}$ & 133 & 53 & 96 & 90 & 186 \\
\hline Miller Lite (Taste Great Less Filling) Promotion & 1978 & $\mathrm{Y}$ & 120 & 52 & 84 & 88 & 172 \\
\hline Lucky Strike Cigarette & 1948 & $\mathrm{~N}$ & 137 & 51 & 95 & 93 & 188 \\
\hline Like A Rock & 1993-2004 & $\mathrm{N}$ & 132 & 50 & 97 & 85 & 182 \\
\hline 1950 Gillette Razor & 1950 & $\mathrm{~N}$ & 139 & 47 & 99 & 87 & 186 \\
\hline Commodore Vic 20 & 1982 & $\mathrm{~N}$ & 139 & 48 & 97 & 90 & 187 \\
\hline California Raisins & 1986 & $\mathrm{Y}$ & 114 & 48 & 88 & 74 & 162 \\
\hline Mama-Mia That's A Spicy Meatball & 1969 & $\mathrm{Y}$ & 139 & 49 & 98 & 90 & 188 \\
\hline New Coke & 1985 & $\mathrm{~N}$ & 115 & 45 & 83 & 77 & 160 \\
\hline Talking Bud-Weis-Er Frogs & 1995 & $\mathrm{Y}$ & 125 & 49 & 90 & 84 & 174 \\
\hline Bird vs. Jordan & 1993 & $\mathrm{Y}$ & 155 & 48 & 104 & 99 & 203 \\
\hline I've Fallen and I Can't Get Up & 1987 & $\mathrm{~N}$ & 134 & 50 & 99 & 85 & 184 \\
\hline Energizer Bunny & 1989 & $\mathrm{Y}$ & 72 & 52 & 67 & 57 & 124 \\
\hline Brain on Drugs & 1987 & $\mathrm{~N}$ & 139 & 48 & 98 & 89 & 187 \\
\hline Morning Again in America & 1984 & $\mathrm{~N}$ & 148 & 47 & 105 & 90 & 195 \\
\hline Bo Knows... & 1989 & $\mathrm{~N}$ & 146 & 47 & 104 & 89 & 193 \\
\hline Nike: Revolution & 1987 & $\mathrm{~N}$ & 146 & 33 & 90 & 89 & 179 \\
\hline Apple McIntosh 1984 & 1984 & $\mathrm{~N}$ & 145 & 41 & 102 & 84 & 186 \\
\hline Crash Dummies & 1980’s (series) & $\mathrm{Y}$ & 137 & 46 & 99 & 82 & 181 \\
\hline Chevy in Technicolor & 1940 & $\mathrm{~N}$ & 137 & 46 & 96 & 85 & 181 \\
\hline Keep America Beautiful & 1970 & $\mathrm{~N}$ & 140 & 46 & 97 & 87 & 184 \\
\hline Dan vs. Dave & 1992 & $\mathrm{Y}$ & 115 & 42 & 84 & 73 & 157 \\
\hline 1958 Edsel & 1958 & $\mathrm{~N}$ & 136 & 44 & 97 & 83 & 180 \\
\hline Budweiser "wassuuup" & 1999 & $\mathrm{Y}$ & 118 & 41 & 87 & 72 & 159 \\
\hline Manning Mastercard & 2006 & $\mathrm{Y}$ & 127 & 45 & 95 & 77 & 172 \\
\hline Oscar Mayer & 1973 & $\mathrm{~N}$ & 131 & 48 & 99 & 80 & 179 \\
\hline Ray Charles/ Pepsi "You got the Right one Baby & 1991 & $\mathrm{~N}$ & 136 & 50 & 99 & 87 & 186 \\
\hline Volkswagen "Funeral" & 1969 & $\mathrm{Y}$ & 137 & 49 & 100 & 86 & 186 \\
\hline Got Milk? & 1993 & $\mathrm{Y}$ & 131 & 46 & 96 & 81 & 177 \\
\hline Little Penny Nike & 1996 & $\mathrm{Y}$ & 130 & 44 & 93 & 81 & 174 \\
\hline Life Cereal & 1972 & $\mathrm{Y}$ & 129 & 44 & 93 & 80 & 173 \\
\hline Kennedy Presidential Campaign & 1960 & $\mathrm{~N}$ & 126 & 45 & 92 & 79 & 171 \\
\hline Daisy Girl & 1964 & $\mathrm{~N}$ & 119 & 32 & 81 & 70 & 151 \\
\hline Magic Vs Bird & 1986 & $\mathrm{~N}$ & 87 & 52 & 75 & 64 & 139 \\
\hline GoDaddy.com & 2005 & $\mathrm{~N}$ & 34 & 11 & 22 & 23 & 45 \\
\hline Monster "When I Grow Up" & 1999 & $\mathrm{Y}$ & 91 & 35 & 71 & 55 & 126 \\
\hline "I'd Like to Teach the World to Sing" Coke & 1971 & $\mathrm{~N}$ & 116 & 35 & 82 & 69 & 151 \\
\hline Max Headroom Coke & 1986 & $\mathrm{~N}$ & 101 & 35 & 72 & 64 & 136 \\
\hline Don't Squeeze the Charmin & 50’s-'70s (series) & $\mathrm{Y}$ & 125 & 35 & 82 & 78 & 160 \\
\hline Federal Express "Fast Paced World" & 1981 & $\mathrm{Y}$ & 101 & 34 & 70 & 65 & 135 \\
\hline Mean Joe Greene/ Coke & 1979 & $\mathrm{~N}$ & 125 & 36 & 84 & 77 & 161 \\
\hline
\end{tabular}




\section{Appendix B.}

P-value Data from Chi-square Test for All Commercials to Detect the Reaction in Terms of Gender and Major

\begin{tabular}{cc}
\hline & Likeability \\
\hline Gender & $\mathbf{0 . 0 0 7 2 1 6}$ \\
Major & $\mathbf{0 . 0 0 1 8 8 4}$ \\
\hline
\end{tabular}

\section{Appendix C.}

Commercials Counts Plot: Difference and non-difference based on Gender

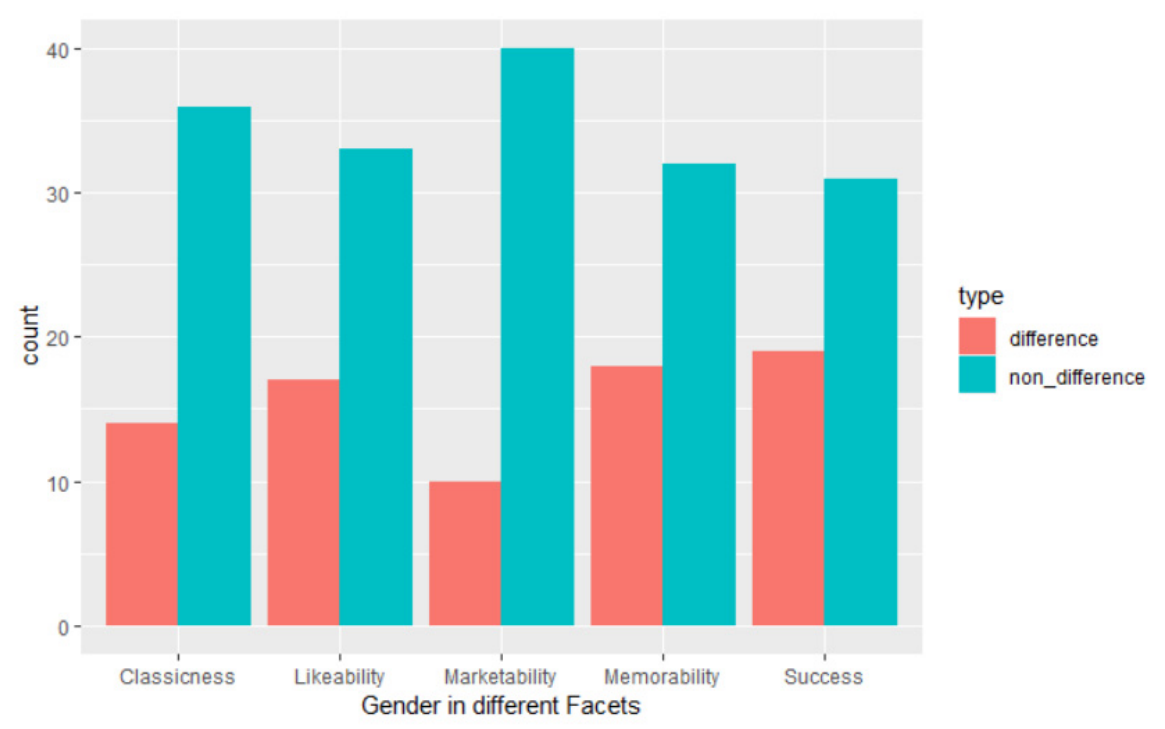

\section{Appendix D.}

Commercials Counts Plot: Difference and non-difference based on Major

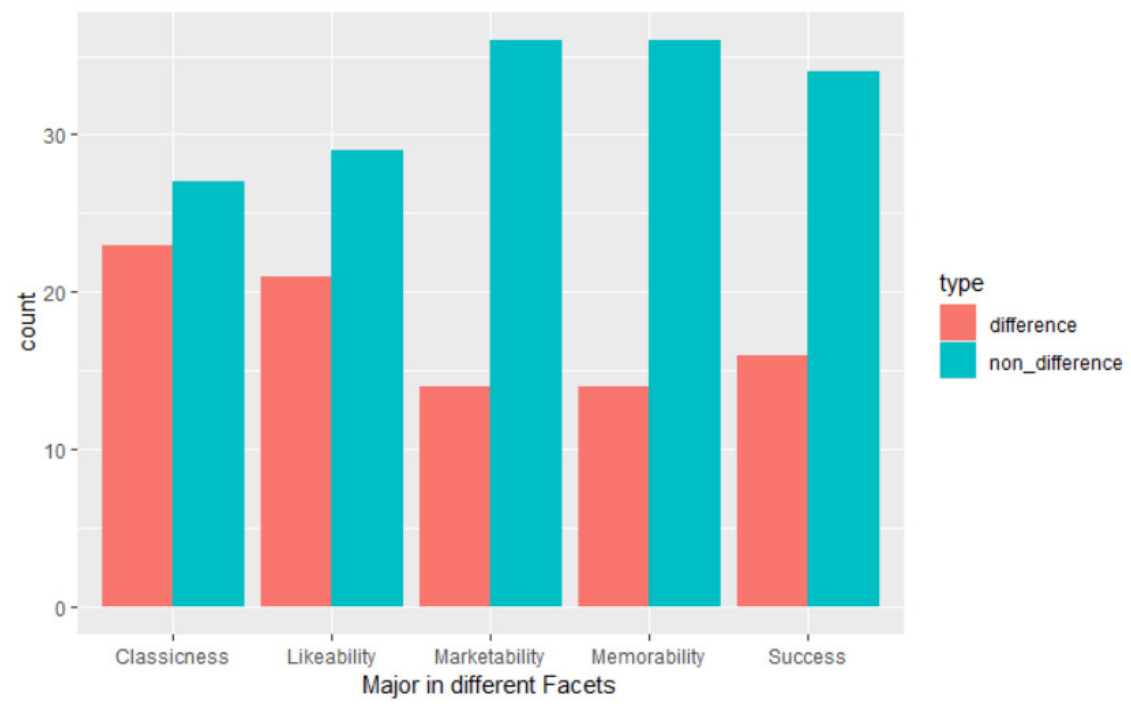




\section{Appendix E.}

Model for Memorability

$$
\begin{aligned}
& \text { Memorability }_{i j m k}=\text { Gender }_{i}+\text { Humor }_{j}+\beta\left(\text { Year }_{i j m k}-\overline{y e a r}\right)+\text { Commercial }_{k} \\
& +(\text { Commercial } * \text { Gender })_{i k}+(\text { Commercial } * \text { Major })_{m k}+\text { error }_{i j m k} \\
& i=j=m=1,2 ; k=1,2,3 \ldots, 50 \text {; } \\
& \text { Commercial }_{k} \sim \mathrm{N}(0,0.12269) \text {; (Commercial * Major) }{ }_{m k} \sim \mathrm{N}(0,0.058) \text {; } \\
& \text { (Commercial } * \text { Gender })_{i k} \sim \mathrm{N}(0,0.0175) \text {; }_{\text {error }} \text { ijmk } \sim \mathrm{N}(0,0.992)
\end{aligned}
$$

\section{Appendix F.}

Model for Marketability

$$
\begin{gathered}
\text { Marketability }_{i j m k}=\text { Gender }_{i}+\text { Humor }_{j}+\text { Commercial }_{k}+\left({\text { Commercial } * \text { Major }_{j m}}_{j m}\right. \\
\text { +error }_{i j m k}
\end{gathered}
$$

\section{Appendix G.}

Model for Chance of Success

$$
\begin{aligned}
& \text { Success }_{i m k}=\text { Gender }_{i}+\text { Commercial }_{k}+\left(\text { Commercial } * \text { Gender }_{i k}\right. \\
& +(\text { Commercial } * \text { Major })_{m k}+\text { error }_{i m k} \\
& i=m=1,2 ; k=1,2,3 \ldots, 50 \text {; } \text { Commercial }_{k} \sim \mathrm{N}(0,0.149) \text {; (Commercial } * \text { Major) } \text { mk }_{k} \sim \mathrm{N}(0 \text {, } \\
& \text { 0.045); (Commercial } * \text { Gender })_{i k} \sim \mathrm{N}(0,0.0169) \text {; }_{\text {error }} \text { imk } \sim \mathrm{N}(0,0.905)
\end{aligned}
$$

\section{Appendix $\mathbf{H}$.}

Model for Classsicness

$$
\begin{aligned}
& \text { Classicness }_{\text {Ijmk }_{k}}=\text { Gender }_{i}+(\text { Gender } * \text { Humor })_{i j} \\
& +\left(\text { Humor } * \text { Major }_{j m}+\left(\text { Gender } * \text { Major }_{i m}+\beta\left(\text { Year }_{i j m k}-\overline{y e a r}\right)\right.\right. \\
& + \text { Commercial }_{k}+(\text { Commercial } * \text { Major })_{m k} \\
& +(\text { Commercial } * \text { Gender } * \text { Major })_{i m k}+\text { error }_{i j m k} \\
& i=j=m=1,2 ; k=1,2,3 \ldots, 50 ; \text { Commercial }_{k} \sim \mathrm{N}(0,0.124) ; \text { error }_{i j m k} \sim \mathrm{N}(0,1.075) \\
& (\text { Commercial } * \text { Major })_{m k} \sim \mathrm{N}(0,0.07557) ;\left(\text { Commercial } * \text { Gender }_{i m k} \sim \mathrm{N}(0,0.01547) ;\right. \\
& \text { * Major })_{i m}
\end{aligned}
$$

\section{Copyrights}

Copyright for this article is retained by the author(s), with first publication rights granted to the journal.

This is an open-access article distributed under the terms and conditions of the Creative Commons Attribution license (http://creativecommons.org/licenses/by/4.0/). 